\title{
Teat Canal Diameter and Other Cow Factors with Possible Influence on Somatic Cell Counts in Cow Milk
}

\author{
By A. Jørstad, T. B. Farver and H. Riemann \\ Department of Epidemiology and Preventive Medicine, \\ School of Veterinary Medicine, University of California, Davis, California, USA.
}

\begin{abstract}
Jørstad, A., T. B. Farver and H. Riemann: Teat canal diameter and other cow factors with possible influence on somatic cell counts in cow milk. Acta vet. scand. $1989,30,239-245$. - A case-control study on matched pairs of cows in 2 counties of Norway indicated a strong positive association between teat canal diameter (TCD) and somatic cell count (SCC) in milk. The study indicated further a highly significant association between leakage of milk and high SCC and a significant association between teat injury and high SCC. Finally, an association between the shape of the teat end and SCC that was nearly significant $(p=.067)$ when considered in isolation, was shown to exist through it's dependency on TCD. A flat or inverted teat end is associated with a large TCD while a pointed or round teat end tends to have a smaller TCD.
\end{abstract}

case-control study; matched pairs; mastitis; teat injury.

\section{Introduction}

Mastitis in dairy cows is a worldwide disease problem accounting for major economic losses (Dobbins 1977). Three interdependent elements are involved in intramammary infections of the dairy cow: microorganisms, the environment and the cow itself. While the importance of the microorganisms and the environment to mastitis is widely recognized, the cow itself is often seen as a passive "element", although a number of studies have reported differences among animals as far as susceptibility to infections is concerned (Lindstrøm et al. 1981, Poutrel 1983).

Cow factors associated with mastitis may be elucidated by comparing cows within herds in case-control studies. In the present study the somatic cell count (SCC) was used as an indicator of udder health status to distinguish between cases and controls. High SCC is associated with inflammation of the ud- der, loss in milk production and inferior milk quality. The most important hypothesis tested was that the teat canal diameter (TCD) does not have the same distribution in high-SCC-cows (cases) as in low-SCCcows (controls).

\section{Materials and methods}

Study design: Norwegian data

A case-control study on matched pairs was conducted to test the importance of some cow factors on SCC in milk. Each pair of cows was matched by herd and lactation number in order to avoid confounding influence on SCC from the cows' environment and their age. A selected case was a cow with an average SCC of more than $500,000 / \mathrm{ml}$ during the last 12 months, and the matched control was a cow with an 
average SCC less than $200,000 / \mathrm{ml}$ during the last 12 months.

The unit of interest was the individual cow, and the inclusion criteria were:

1) The cow belonged to a herd that was a member of The Norwegian National Board of Animal Production Recording (NNBAPR).

2) Both cows in a pair belonged to the same herd and the lactation number of the high SCC-cow was equal to the lactation number of the low SCC-cow.

3) Neither cow in a pair showed signs of acute mastitis and the low SCC-cow yielded milk from all 4 quarters.

\section{Data collection}

Data were merged from 3 sources:

1) Data on SCC and lactation number were obtained from NNBAPR records.

2) Data on the disease variables were obtained from health records provided by Norwegian Cattle (NRF), the major breeding association for cattle in Norway.

3) Data on other cow factors were obtained by examining the case and control cows during a herd visit.

The study was conducted in 2 regions of Norway during the fall of 1982 and the spring of 1983. Data on 28 matched cow pairs from 26 herds were collected in Hedmark county (Nord-Østerdal) during the fall of 1982, and 10 pairs from 9 herds were sampled and investigated in Troms county during the spring of 1983. All the cows were of the NRF-breed and the average herd size was 15 in Hedmark county and 8 in Troms county.

\section{Factor definitions}

The independent variables for the Norwegian data consisted of:

Teat injuries, previous lactations $(1=$ yes, 0 $=$ no).
Teat injuries, this lactation $(1=$ yes, $0=$ no $)$. Mastitis, previous lactations $(1=$ yes, $0=$ no).

Mastitis, this lactation $(1=$ yes, $0=$ no $)$.

Shape of udder $(1=$ bowl, $2=$ sack $)$.

Shape of teat $(1=$ funnel, $2=$ cylinder $)$.

Shape of teat end $(1=$ flat, $2=$ round $)$. Inversion of teat tip (yes $=1$, no $=0$ ).

Teat canal diameter (TCD), measured by "Spenometer I. O." according to the procedure described by Grondahl (1975).

Leakage of milk from any teat (yes $=1$, no $=$ $0)$.

Present injury to teat tip caused by milking machines $(0=$ no, $1=$ white ring around teat canal orifice, 2 = erosion of teat tip, $3=$ induration of teat canal).

Present injury to teat tip caused by cow $(0=$ no, $1=$ yes.

The length of the cow in $\mathrm{cm}$.

The size of the cow as width of the chest in $\mathrm{cm}$.

The dependent variable was SCC $\times 10^{3} / \mathrm{ml}$ milk as recorded every 2 nd month by the NNBAPR on Fossomatic equipment.

\section{Study design: Californian data}

In addition to these 38 matched cow pairs from Norway, data on TCD and shape of teat end from 34 cases and 48 controls were collected in Sacramento county in California during the spring of 1984 . All the data from California were from the same herd, a commercial dairy of approximately 450 milk cows of Holstein breed.

\section{Data collection}

Data were merged from 2 sources:

1) Data on SCC and bacteriological examinations were provided by Extension Services, University of California, Davis.

2) Data on TCD and shape of teat end were obtained by examining the case and control cows during a herd visit. 
The independent variables for the Californian data consisted of:

1) Shape of teat end ( $1=$ flat, $0=$ round).

2) Teat canal diameter (TCD), $1 / 10 \mathrm{~mm}$ by "Spenometer I. O.".

The dependent variables for the Californian data:

1) Somatic cell count (SCC) as recorded by the Californian Dairy Herd Improvement Association (CDHIA).

2) Test results from bacteriological examination of quarterly milk samples for detection of udder pathogens.

\section{Statistical analysis}

Statistical analysis was performed using McNemar's odds ratio and Chi-square for matched pairs and dichotomous exposure. In this analysis one uses only the discordant pairs, in which only the case or only the control has been exposed (Breslow \& Day 1980). Confidence limits for the McNemar's Chi-square were calculated according to (Pearson \& Hartley 1970).

Student t-test for paired data was used on continuous data, and the BMDPLR computer program (Dixon 1983) was used for stepwise logistic regression on the independent variables TCD and shape of teat end from the Californian data. TCD was used in it's original continuous format.

Due to the large herd-size and a Str. agalactiae problem in the Californian dairy, several cases and several controls were selected in each specific stratum (lactation number). Thus an unconditional logistic regression could be applied to those data without jeopardizing the validity of the analysis.

\section{Results}

\section{Norwegian data}

Table 1 shows that teat injury during previous lactations was found to be significantly associated with the level of SCC in the milk. $(\mathrm{p}<.025)$.

Mastitis in the current lactation was significantly associated with high SCC $(\mathrm{p}<.01)$, while mastitis during previous lactations was not.

Two other dichotomous variables were significantly associated with high SCC at the $5 \%$ level: leakage of milk with $\mathrm{p}<.005$ and inversion of teat ends with $\mathrm{p}<.01$.

Table 2 shows that teat canal diameter (TCD) was the factor with the most significant influence on SCC at the $5 \%$ level among the continuous variables ( $p<$ .0001).

Size of cow measured as width of chest was also significantly associated with SCC (p $<.01)$.

\section{Californian data}

To confirm the highly significant association between TCD and SCC, to assess the importance of the shape of the teat end to SCC and to ascertain whether there was any interaction between TCD and the shape of the teat end (TCD * Shape), a stepwise logistic regression was applied to the Californian data. The results were (Table 3 ):

1) No significant interaction term TCD * Shape;

2) Highly significant effect of TCD;

3) No effect of shape of teat end with TCD already in the equation.

To assess the reliability of using SCC as the dependent variable measuring the udder health status, a 2 nd set of runs was made using as a dependent variable the results of the bacteriological findings from examination of quarterly milk samples (Table 3). Due to a positive Str. agalactiae diagnosis on 12 of the 48 control cows and no findings of major udder pathogens (contamination) on 6 of the 34 case cows, the results of these runs were then based on 28 cases which had 
Table 1. Results of McNemars odds ratio and Chi-square measurement of association between the independent categorical variables and SCC in milk on the Norwegian data.

\begin{tabular}{|c|c|c|c|c|c|}
\hline Variable & Odds ratio & Chi-square & P-value & $95 \%$ C. I. & Comment \\
\hline Shape of udder & $9 / 5=1.8$ & 0.64 & Non sign & & \\
\hline Shape of teats & $7 / 4=1.75$ & 0.09 & Non sign & & \\
\hline Shape of teat ends & $12 / 4=3$ & 3.06 & $0.05<\mathrm{p}<0.1$ & & \\
\hline $\begin{array}{l}\text { Teat injuries } \\
\text { previous lactations }\end{array}$ & $7 / 0$ & $(5.14)$ & $\mathrm{p}<0.024^{*}$ & $(1.44 ; \infty)$ & \\
\hline Teat injuries this lactation & $1 / 1=1$ & 0.5 & Non sign & & \\
\hline $\begin{array}{l}\text { Mastitis treatment } \\
\text { previous lactations }\end{array}$ & $8 / 6=1.33$ & 0.07 & Non sign & & \\
\hline $\begin{array}{l}\text { Mastitis treatment } \\
\text { this lactation }\end{array}$ & $14 / 2=7$ & 7.56 & $\mathrm{p}<0.01^{* *}$ & $(1.61 ; 49)$ & \\
\hline $\begin{array}{l}\text { Teat injuries due } \\
\text { to incorrect milking }\end{array}$ & $9 / 5=1.8$ & 0.64 & Non sign & & \\
\hline $\begin{array}{l}\text { Observed teat injuries } \\
\text { due to trauma }\end{array}$ & $3 / 0 \rightarrow \infty$ & 1.33 & Non sign & & \\
\hline $\begin{array}{l}\text { Leakage of milk } \\
\text { between milkings }\end{array}$ & $12 / 0 \rightarrow \infty$ & 10.08 & $\mathrm{p}<0.005^{* *}$ & $(2.78 ; \infty)$ & $\begin{array}{l}\text { rely on the } \\
\text { farmers memory }\end{array}$ \\
\hline Inversion of teat end & $9 / 0 \rightarrow \infty$ & 7.11 & $\mathrm{p}<0.01$ & $(1.97 ; \infty)$ & \\
\hline
\end{tabular}

$*$ significant at $5 \%$ level

** $=$ signifikant at $1 \%$ level

*** $=$ signifikant at $0.1 \%$ level

Table 2. Results of Student t-test for paired data on interval variables from the Norwegian data.

\begin{tabular}{lccccl}
\hline Variable & Mean & ST DEV & Se Mean & T-values & P-value \\
\hline $\begin{array}{l}\text { Teat canal diameter } \\
\text { Length of cow }\end{array}$ & 3.06 & 3.48 & 0.57 & 5.41 & $\mathrm{p}<0.0001^{* * *}$ \\
$\begin{array}{l}\text { Size of cow measured } \\
\text { as width of chest }\end{array}$ & 1.52 & 5.61 & 0.96 & 1.96 & $\mathrm{p}=0.059$ \\
\hline
\end{tabular}

\footnotetext{
${ }^{*}=$ significant at $5 \%$ level

$* *$ significant at $1 \%$ level

*** $=$ significant at $0.1 \%$ level
}

major udder pathogens and high SCC, and 36 controls which had no udder pathogens and low SCC. The results were:

1) No significant interaction TCD * Shape at $5 \%$ level;

2) Highly significant effect of TCD;

3) No effect of shape of teat end with TCD in the equation.

\section{Discussion}

Teat canal diameter (TCD) measured by "Spenometer I. O." is the cow factor expressing itself as highly significant both in the Norwegian and the Californian data, meaning that a cow with a wide (large) TCD is more likely to have high SCC than a cow with a narrow TCD. This is in agreement 
Table 3. Comparison of the results obtained for the Norwegian and the Californian data with logistic regression on TCD and shape of teat end.

\begin{tabular}{|c|c|c|c|}
\hline & \multirow{2}{*}{$\begin{array}{l}\text { Norwegian data } \\
\text { Dependent } \\
\text { variable = SCC }\end{array}$} & \multicolumn{2}{|c|}{ Californian data } \\
\hline & & $\begin{array}{l}\text { Dependent } \\
\text { variable }=\text { SCC }\end{array}$ & $\begin{array}{l}\text { Dependent variable }= \\
\text { results of bacteriological } \\
\text { examination on quarterly } \\
\text { milk samples }\end{array}$ \\
\hline Main effect of TCD & $\mathrm{p}=0.0007^{* * *}$ & $\mathrm{p}=0.0002^{* * *}$ & $\mathrm{p}=0.0001^{* * *}$ \\
\hline $\begin{array}{l}\text { Main effect of } \\
\text { shape of teat end }\end{array}$ & $\mathrm{p}=0.0401^{*}$ & $\mathrm{p}=0.0672$ & $\mathrm{p}=0.0965$ \\
\hline $\begin{array}{l}\text { Effect of TCD controlling } \\
\text { for shape of teat end }\end{array}$ & $\mathrm{p}=0.0039^{* *}$ & $\mathrm{p}=0.0026^{* *}$ & $\mathrm{p}=0.0031^{* *}$ \\
\hline $\begin{array}{l}\text { Effect of shape of teat end } \\
\text { controlling for TCD }\end{array}$ & $\mathrm{p}=0.7251$ & $\mathrm{p}=0.8277$ & $\mathrm{p}=0.9870$ \\
\hline $\begin{array}{l}\text { TCD * Shape interaction } \\
\text { with both main effects } \\
\text { in equation }\end{array}$ & $\begin{array}{l}\mathrm{p}=0.1076 \text { of } \\
\text { entering }\end{array}$ & $\begin{array}{l}\mathrm{p}=0.1473 \text { of } \\
\text { entering }\end{array}$ & $\begin{array}{l}\mathrm{p}=0.0603 \text { of } \\
\text { being removed }\end{array}$ \\
\hline
\end{tabular}

with McDonald (1975) who used an in vivo radiographic method to determine teat canal anatomy. $\mathrm{He}$ found that quarters resistant to intramammary infections (IMI) had teat canals with a smaller diameter than those of susceptible quarters.

Thiel et al. (1969) found that cyclical and irregular vacuum fluctuations causing "impact", i. e. milk droplets injected as a jetspray from the claw towards the teat end through the short tube, increased the risk of mastitis. The risk of impacts entering the teat sinus might be enhanced by a large TCD.

Bakken (1981) found that many of the milking plants (set ups) in 5 different counties of Norway had major flaws causing insufficient capacity. This would be expected to result in irregular vacuum fluctuations and "flooding" of the liners with milk from the claw. Thus cross-infections among quarters in the infected cow, or transmission of bacteria from a previously milked cow might be expected. A flat teat end was nearly significantly associated with high SCC $(\mathrm{p}<.067)$. However, the effect of the shape of the teat end disappears as soon as TCD is taken into account and corrected for. Thus, the shape of the teat end seems to be confounded by its association with TCD.

Looking at the disease variables from the health records, it is not surprising to find that teat injury during previous lactations is significantly associated with high SCC as shown by the general experience that teat injury is an important cause of mastitis and thus of high SCC in milk. Teat injury this lactation is not significant at $5 \%$ level, probably due to effect preceeding cause (SCC used in the study are measured before the teat injury) and small numbers.

The absence of association between mastitis during the previous lactation and high SCC compared to the high association between 
mastitis this lactation and SCC might indicate that there is a considerable difference in the response of the cows to intramammary infections. Another possible explanation is that farmers and veterinarians are now using SCC in milk as an indicator of cows needing mastitis examination and treatment.

Leakage of milk between milkings is due to loss of sphincter efficiency (Murphy 1944) and might promote infection through backflow of milk through the open teat canal as pressure within the teats and the udder changes. It might also result from heavy contamination of teats and udder because of growth of microorganisms in the spilled milk.

Size of cow measured as width of chest was significantly associated with SCC meaning that large cows had a higher SCC than small cows. This finding may be explained by the enhanced risk of teat injuries in large cows when the stall is too small.

In summary, 3 cow factors appear to be associated with high SCC in milk in the present study. Teat canal diameter (TCD), teat injury and increased sphincter patency are all cow factors that make biological sense. The teat canal is the gateway through which the microorganisms have to invade in order to establish an IMI, and both teat injuries and leakage of milk promote the growth of udder pathogens.

\section{Acknowledgements}

Mr. Rolf Bjerke-Larssen of the National Veterinary Institute is cordially thanked for his kind assistance in planning this study.

\section{References}

Bakken G: An epidemiological study of bovine mastitis: With special reference to bacteriological and environmental determinants. Thesis. National Veterinary Institute, Oslo 1981.
Breslow NE, Day NE: Statistical Methods in Cancer Research. Vol. 1. The analysis of casecontrol studies. International Agency for Research of Cancer, Lyon 1980. (IARC Scientific publications no. 32).

Dixon WJ (ed.): BMDP Statistical Software. University of California Press. 1983.

Dobbins CNJ: Mastitis losses. J. Amer. vet. med. Ass. 1977, 170, 1129-1132.

Grondahl J: Utmelkingsegenskap hos ku i relasjon til spenekanaldiameter; spenekanal målt med spenometer på levende ku, melkestrøm registrert med elektronisk milkograf. (Milking-out characteristics in the cow in relation to teat canal diameter; teat canal measured with the spenometer in the living cow; milk flow registered with an electronic milkograph). Thesis. Norwegian College of Veterinary Medicine, Oslo 1975.

Kingwill $R G$, Dodd $F H$, Neave $F K$ : Machine milking and mastitis. In: Machine milking. Thiel CC, Dodd FH. (eds.) National Institute for Research in Dairying 1977, p. 231-285.

Lindstrøm UB, Kenttamies M, Arstila J, Tuovila $R$ : Usefulness of cell counts in predicting bovine mastitis. Acta Agric. scand. 1981, 31, 199-263.

McDonald JS: Radiographic method for anatomic study of the teat canal: Characteristics related to resistance to new intramammary infection during lactätion and the early dry period. Cornell Vet. 1975, 65, 492-499.

Murphy JM: The relationship of teat patency to udder infection. Cornell Vet. 1944, 34, 64-68.

Pearson ES, Hartley HO (eds.): Biometrika Tables for Statisticians. Cambridge University Press. London 1970-1972.

Poutrel B: La sensibilité aux mammites: Revue des facteurs liés à la vache. (Susceptibility to mastitis: A review of factors related to the cow). Ann. Rech. vet. 1983, 14, 89-104.

Thiel CC, Thomas CL, Westgarth DR, Reiter B: Impact force as a possible cause of mechanical transfer of bacteria to the interior of the cow's teat. J. Dairy Res. 1969, 36, 279-297.

Thiel CC, Thomas CL, Westgarth DR, Neave FK: The influence of some physical characteristics of the milking machine on the rate of new 
mastitis infections. J. Dairy Res. 1973, 40, 117-129.

\section{Sammendrag}

Spenekanaldiameter og andre kufaktorer med mulig innvirkning på det somatiske celletallet i kumelk.

Data til en "case-control" studie ble samlet høsten 1982 og våren $1983 \mathrm{i}$ to fylker i Norge for å undersøke sammenhengen mellom nærmere definerte kufaktorer og det somatiske celletallet i melk.

I tillegg ble det samlet data for 34 "cases" og 48 kontrollkyr i California våren 1984.
Det norske forsøket viste en sterk positiv sammenheng mellom spenekanaldiameter og celletallet $\mathrm{i}$ melk. Videre var det en positiv sammenheng mellom lekkasje og høyt celletall, og mellom speneskader og høyt celletall i melka.

Forsøket i California viste samme sterke sammenheng mellom vide spenekanaler og høyt celletall i melka som ved det norske. I tillegg viste dette forsøket at resultatet ble det samme hvis en benyttet bakteriologiske undersøkelser av enkeltspeneprøver som avhengig variable i stedet for det somatiske celletallet.

(Received March 5, 1988; accepted August 18, 1988).

Reprints may be requested from: Asbjørn Jørstad, 2660 Dombås, Norway. 
